\title{
DETECTION OF LISTERIA SPP. IN RAW MILK AND DAIRY PRODUCTS RETAILED IN ANKARA
}

\author{
Pınar Şanlıbaba ${ }^{1 *}$, Başar Uymaz Tezel², Gürcü Aybige Çakmak ${ }^{3}$ \\ ${ }^{1}$ Ankara University Engineering Faculty, Department of Food Engineering, Gölbaşı, Ankara, Turkey \\ ${ }^{2}$ Çanakkale Onsekiz Mart University Bayramiç Vocational School, Food Technology Program, Bayramiç, \\ Çanakkale, Turkey \\ ${ }^{3}$ Akdeniz University Engineering Faculty, Department of Food Engineering, Antalya, Turkey
}

Received / Geliş: 28.11.2017; Accepted / Kabul: 19.02.2018; Published online / Online bask1: 08.03.2018

Şanlıbaba, P., Uymaz Tezel, B., Çakmak, G. A. (2018). Detection of Listeria spp. in raw milk and dairy products retailed in Ankara. GIDA (2018) 43 (2): 273-282 doi: 10.15237/gida.GD17107

\begin{abstract}
The objective of this study was to determine the prevalence of Listeria species in raw milk, and dairy products. A total of 110 samples were obtained from randomly selected retail stores and local bazaars located in Ankara. Using TS EN ISO 11290-1 method, 23 samples were found positive for Listeria spp. The overall prevalence of Listeria spp. was $20.91 \%$, in which L. innocua was the most commonly recovered species $(6.36 \%)$. The remaining isolates were identified as $L$ ivanovii $(5.45 \%), L$. monocytogenes $(4.55 \%)$, and $L$ welshimeri $(4.55 \%)$. The $L$ monogytogenes isolates were positive for the presence of $b y \mathrm{~A}$ gene. The highest prevalence of Listeria spp. was found in homemade cheese $(9.09 \%)$, followed by raw milk $(8.19 \%)$, and white cheese (3.64\%). L monocytogenes was isolated from raw milk and homemade cheese in this study.

In conclusion, the low hygienic quality dairy products may lead to listeriosis surveillance in Ankara.
\end{abstract}

Keywords: Listeria, milk, dairy products, identification

\section{ANKARA’DA SATIŞA SUNULAN ÇİĞ SÜT VE SÜT ÜRÜNLERİNDE LISTERIA SPP. VARLIĞININ BELIRLENMESİ}

\section{ÖZ}

$\mathrm{Bu}$ çalışmada çiğ süt ve süt ürünlerinde Listeria türlerinin yaygınlığının saptanması amaçlanmıștır. Ankara'da bulunan ve rastgele seçilen market ve pazarlardan toplam 110 örnek alınmıştır. TS EN ISO 11290-1 yöntemi kullanılarak, toplam 23 örnek Listeria spp. varlığı bakımından pozitif bulunmuştur. Analize alınan örneklerde Listeria türlerinin bulunma sıklığ1 \%20.91 olarak tespit edilmiş, L. innocua (\%6.36) ise en fazla rastlanan tür olarak belirlenmiştir. Geri kalan izolatlar ise L. ivanovii (\%5.45), L. monocytogenes (\%4.55) ve L. welshimeri (\%4.55) olarak tanımlanmıştır. L. monocytogenes suşları blyA gen bölgesi varlığı bakımından pozitif olarak saptanmıştır. En yüksek Listeria spp. prevalansı ise, sırasıyla ev yapımı peynir (\%9.09), çiğ süt (\%8.19) ve beyaz peynirde (\%3.64) saptanmıştır. Bu çalışmada $L$. monocytogenes suşları çiğ süt ve ev yapımı peynirlerden izole edilmiştir.

Sonuç olarak hijyenik kalitesi düşük süt ürünlerinin, listeriosis surveyansını Ankara'da artırabileceği gözlemlenmiştir.

Anahtar kelimeler: Listeria, süt, süt ürünleri, tanımlama

${ }^{*}$ Corresponding author/Yazışmalardan sorumlu yazar;

\sanlibab@ankara.edu.tr, @ (+90) 312203 3300/3617, 且 (+90) 3123178711 


\section{INTRODUCTION}

Listeria spp. is Gram positive and facultative anaerobic organisms. They are also non-spore forming, and rod-shaped bacteria (Momtaz and Yadollahi, 2013; Odetokun and Adetunji, 2016). All six Listeria spp. (L. monocytogenes, L. seeligeri, L. ivanovii, L. welshimeri, L. innocua, L. grayi) which were identified before 1985 can be isolated from foods. These strains referred to as "classic" Listeria spp. (Barre et al., 2016). L. monocytogenes and $L$. ivanovii are the two known pathogenic species within this genus. Although $L$. monocytogenes may lead to illness and death in humans and other mammals, $L$. ivanovii is primarily associated with ruminant animals (Hellberg et al., 2013). The genus Listeria consists of 17 species and 4 subtypes on the basis of $16 \mathrm{~S}$ rRNA sequences so far (Anonymous, 2017).

Listeriosis is one of the most important bacterial infections worldwide. This infection arises mainly from the consumptions of contaminated foods. According to reports of Centers for Disease Control and Prevention (CDC), an estimated 1.600 people get sick from Listeria each year, and about 260 die (Anonymous, 2018a). Furthermore, listeriosis affected about 2.200 people in 2015, causing 270 deaths. The highest number of this rates ever reported in the EU. The proportion of cases in the over 64 age group steadily increased from $56 \%$ in 2008 to $64 \%$ in 2015 (Anonymous, 2018b). In Turkey, listeriosis was first detected in 1945, but rare cases were reported in human, and the epidemic was not found (Anonymous, 2018c). L. monocytogenes is one of the most important pathogens responsible for foodborne illness which may result in meningitis, septicemia, spontaneous abortion, perinatal infections and gastroenteritis. L. monocytogenes is characterized into 13 different serotypes. 1/2a, $1 / 2 \mathrm{~b}, 1 / 2 \mathrm{c}$, and $4 \mathrm{~b}$ are pathogenic serotypes of which $1 / 2 \mathrm{a}, 1 / 2 \mathrm{~b}$, and $4 \mathrm{~b}$ are responsible for $98 \%$ human listeriosis. While $1 / 2 \mathrm{a}, 1 / 2 \mathrm{~b}, 4 \mathrm{~b}$ are isolated from the clinical cases, $1 / 2 \mathrm{a}$ is mostly isolated from foods (Soni et al., 2013; Barre et al., 2016; Reda et al., 2016). The major risk population groups at risk for invasive listeriosis are the immunocompromised such as pregnant women, unborn or newly delivered infants, organ transplant recipients, cancer and AIDS patients, and the elderly, with fatality rates of $20-30 \%$ (Yehia et al., 2016; Phraephaisarn et al., 2017). Different environments such as soil, surface water, sewage, animal feed, farm environments, food processing equipments and environments, urban and suburban settlements are found be contaminated with Listeria spp. (Korsak and Szuplewska, 2016). Various food types such as raw and processed foods also can become contaminated with Listeria species. These foods are raw milk and dairy products, various meats and meat products such as beef, fermented sausages, fish products, ready-to-eat foods, and vegetables (Saludes et al., 2015).

Milk and dairy products have high nutritional value. Hence, these food products are very suitable for development of microorganisms, including pathogenic bacteria. Listeria species are commonly found in the dairy environment, on the farm and in the processing plants (Sarfaz et al., 2017). One of the most common paths for transmission of L. monocytogenes is raw milk in dairy industry. Pasteurization of milk which occurs at the temperature of $62.8{ }^{\circ} \mathrm{C}$ for 30 minutes and $71.7{ }^{\circ} \mathrm{C}$ for 15 seconds is enough to destroy Listeria spp. present in the population of $10^{2}$ $\mathrm{CFU} / \mathrm{mL}$. Soft, white and fresh cheeses are also suitable for growth of $L$. monocytogenes. Moreover, in semi-hard cheeses are excellent for reproduction of $L$. monocytogenes (Kasalica et al., 2011). L. monocytogenes can be transmitted by the consumption of homemade cheeses which are produced from unpasteurized milk (Arslan and Özdemir, 2008). According to CDC reports annually, about 800 laboratory-confirmed cases of listeriosis linked to several types of cheeses are reported each year in the United States, and typically 3 or 4 outbreaks are identified. In 2017, 8 confirmed listeriosis were reported in the United States as a result of consume of raw milk cheeses, and 2 die occurred (Anonymous, 2018a). In accordance with Turkish Food Codex, there should not be any $L$. monocytogenes in each $25 \mathrm{~g} / \mathrm{mL}$ of dairy products (Anonymous, 2011). 
The aim of the present work was to provide information about Listeria spp. strains isolated from raw milk and dairy products produced in Ankara (Turkey), focusing on their prevalence, phenotypic and genotypic characteristics.

\section{MATERIALS AND METHODS \\ Sampling}

In the period February 2016 to July 2016, a total of 110 samples of which 25 were raw milk, 25 pasteurized milk, 30 white cheeses, and 30 homemade cheeses, which were randomly purchased from various local bazaars and supermarkets in Ankara, Turkey. The food samples were transported to the laboratory under cold conditions on the sampling day and analyzed immediately.

\section{Bacterial Strains and Culturing}

Listerial strains isolated in this study and the reference strain (L. monocytogenes ATCC 7644) were propagated on Tryptic Soy Broth supplemented with $0.6 \%$ of yeast extract (TSBYE) (Sigma, Germany). They were grown at $35^{\circ} \mathrm{C}$ for $24 \mathrm{~h}$. The initial isolates of strains were stored at $-20{ }^{\circ} \mathrm{C}$ with $30 \%(\mathrm{v} / \mathrm{v})$ glycerol (Merck, Germany).

The reference strain of L. monocytogenes ATCC 7644 was obtained from the culture collection of Food Microbiology Culture Collections, Department of Food Engineering, Engineering Faculty, Ankara University, Ankara, Turkey.

\section{Isolation and identification of Listeria spp.}

Isolation and identification of Listeria spp. were carried out according to the International Organization for Standardization (TS EN ISO 11290-1) procedure. Two-step method for enrichment of Listeria spp. was performed in accordance with the standard. 25 grams of cheeses were added to $225 \mathrm{~mL}$ of $1 / 2$ Fraser broth (Merck, Germany) as the first selective enrichment medium. It was homogenized in a stomacher-400 (London, UK) at high speed for two minutes and incubated for $24 \pm 2 \mathrm{~h}$ at $30 \pm 1$ ${ }^{\circ} \mathrm{C}$. Similarly, $25 \mathrm{~mL}$ of milk was sampled and $\mathrm{pH}$ adjusted to neutral and thoroughly mixed with 1:10 ratio to $1 / 2$ Fraser broth and incubated at
$30 \pm 1{ }^{\circ} \mathrm{C}$ for $24 \mathrm{~h}$. After first enrichment step, 0.1 $\mathrm{mL}$ of $1 / 2$ Fraser broth culture was transferred to $10 \mathrm{~mL}$ of Fraser broth as a secondary enrichment medium and incubated at $37{ }^{\circ} \mathrm{C}$ for $48 \pm 2 \mathrm{~h}$. At the same time, after primary enrichment incubation, a loopfull of culture was streaked onto ALOA (Agar Listeria Ottaiani Agosti) agar (Merck, Germany) and PALCAM (Polmixin Acriflavin Lithium Chloride Ceftazidime Aesculin Mannitol) agar (Merck, Germany) and incubated for $24-48 \mathrm{~h}$ at $37^{\circ} \mathrm{C}$. In a similar vein, incubation a loopfull of secondary enrichment culture was streaked onto ALOA and PALCAM agar plates and incubated, at $37{ }^{\circ} \mathrm{C}$ for $24-48 \mathrm{~h}$. It was observed grey-green colonies with black background on PALCAM agar plates, which is typical for Listeria spp. Typical green-blue colored colonies with and without a distinctive opaque colonies were determined on ALOA agar. Three to five presumptive colonies from ALOA and PALCAM agar were re-streaked on Tryptic Soy Agar supplemented with $0.6 \%$ of yeast extract (TSA-YE) (Sigma, Germany) at $37{ }^{\circ} \mathrm{C}$ for $24-48$ h. Typical colonies from TSA-YE (1 $\mathrm{mm}$ to $2 \mathrm{~mm}$ in diameter, convex, colourless and opaque) were subjected to standard biochemical tests including gram staining, determination of catalase activity, oxidase activity, and stabbed into Listeria Motility Medium (Sigma, Germany) at $25{ }^{\circ} \mathrm{C}$ and $35{ }^{\circ} \mathrm{C}$ for observing the characteristics umbrella motility. The isolated and characterized strains were identified using API Listeria test system according to the manufacturer recommendations (BioMeriux, France). The reference strain $L$. monocytogenes ATCC 7644 was used in all biochemical tests.

\section{Molecular identification}

Bacterial genomic DNA was extracted from the bacterial cells grown at $35^{\circ} \mathrm{C}$ overnight in TSBYE using genomic DNA extraction kit (Thermo Fisher Scientific), following the manufacturer's instructions. The DNA was stored at $-20^{\circ} \mathrm{C}$. The primer pairs designated as $907 \mathrm{r}$ (CCGTCAATTCCTTTGAGTTT') and 27f (AGAGTTTGATCCTGGCTCAG) proposed by Beasley and Saris (2004) were used to amplify a $900 \mathrm{bp}$ region in the $16 \mathrm{~S}$ rRNA gene for the detection of Listeria genus. In addition, primer 
pairs designated as F:GCAGTTGCAAGCGCTTGGAGTGAA and R:GCAACGTATCCTCCAGAGTGATCG were used to detect $L$. monocytogenes isolates harbouring bly A gene that amplify a $456 \mathrm{bp}$ fragment (Paziak-Domanska et al., 1999). Polymerase chain reaction (PCR) amplification was performed in $50 \mu \mathrm{L}$ of a reaction mixture containing $5 \mu \mathrm{L}$ of PCR buffer, $1 \mu \mathrm{L}$ of $2 \mathrm{mM}$ of deoxynucleoside triphospate mix, $1 \mu \mathrm{L}$ of each primer, $34.75 \mu \mathrm{L}$ of sterile distilled water, $0.25 \mu \mathrm{L}$ of Tag DNA polymerase, $4 \mu \mathrm{L}$ of $25 \mathrm{mM} \mathrm{MgCl} 2$ and $3 \mu \mathrm{L}$ of the DNA template solution (Blaiotta et al., 2002). PCR amplification was carried out in a programmed ThermoCycler (Techne TC-512, Staffordshire, UK) with following by 35 cycles each, of 2 minutes denaturation at $95^{\circ} \mathrm{C}, 45 \mathrm{sec}$ annealing at $55^{\circ} \mathrm{C}, 2$ minutes extension for $72{ }^{\circ} \mathrm{C}$, and final extension at $72{ }^{\circ} \mathrm{C}$ for 7 minutes. PCR products were electrophoresed in 1\% agarose gel, stained with ethidium bromide at $80 \mathrm{~V}$ for 45 minutes and visualized under UV illuminator (SYNGENE, Biosystems UK). A 10000 bp DNA molecular ladder was included to determine the size of the amplified products.

\section{RESULTS AND DISCUSSION}

A total of 110 samples were examined for the presence of Listeria spp. using two step selective enrichment recommended by TS EN ISO 112901 method, which is based on biochemical identification of suspected colonies on ALOA and PALCAM agar plates. Of 110 samples analyzed, 23 were found as Listeria spp. positive. All isolates were found to be Gram positive, catalase positive, oxidase negative, and the characteristics umbrella motility was observed in a motility medium. In addition, API ${ }^{2}$ Listeria test kit was used to species-level identification of 23 isolates (data not shown). The PCR results were used as final confirmation to identify of presumptive colonies isolated in this study (Figure 1). Incidence of Listeria spp. and L. monocytogenes was summarized in Table 1. The counts of Listeria spp. were distributed as follows: $6.36 \%$ to $L$. innocua, $5.45 \%$ to $L$. ivanovii, $4.55 \%$ to $L$. monocytogenes, and $4.55 \%$ to $L$ welshimeri. All of the five $L$. monocytogenes isolates were determined to have the bly $\mathrm{A}$ gene (Figure 2). The remaining
Listeria isolates tested negative for the by A gene according to PCR. L. monocytogenes was isolated from raw milk and homemade cheese in this study. The highest prevalence of Listeria spp. was detected in homemade cheese $(9.09 \%)$, followed by raw milk $(8.19 \%)$, and white cheese $(3.64 \%)$. As it can be seen from Table 1, L. innocua was the most prevalent species isolated from the samples, which is followed by $L$. ivanovii. This finding was in agreement with earlier reports (Gebretsadik et al., 2011; Rahimi et al., 2012; Jamali et al., 2013). The incidence of $L$. innocua was $6.36 \%$. L. innocua is an indicator of the presence of $L$. monocytogenes. Furthermore, this strain has been used as a surrogated for the study of $L$. monocytogenes in a variety of food systems (Milillo et al., 2012). L. ivanovii cause animal and human infections with $L$. monocytogenes (Seyoum et al., 2015). Incidence of $L$. ivanovii $(5.45 \%)$ obtained in this study was also worrying. Therefore, this prevalence rate is a risk factor in human body causing infections. Moreover, the identification of non-pathogenic Listeria spp. in current study was important. These non-pathogenic species have been found to cause disease in both immunocompenent and immunocompromised individuals (Usman et al., 2016).

We did not found any Listeria spp. from pasteurized milk, in agreement with Sarker and Ahmed (2015). In contrast to our findings, 16.7\% of unclean pasteurized milk was obtained by Silva et al. (2003). Natratilova et al. (2004) stated that Listeria spp. was found to be $5 \%$ in Czech Rebuplic. In addition, $40 \%$ of pasteurized milk was found to be contaminated with Listeria spp. in Ethiopia (Seyoum et al., 2015). Contamination after pasteurization or faults of technology during pasteurization are responsible for the presence of Listeria spp., specially $L$. monocytogenes. These reports show that thermal process like pasteurization does not give any way guarantee the absolute safety of milk and dairy products. 


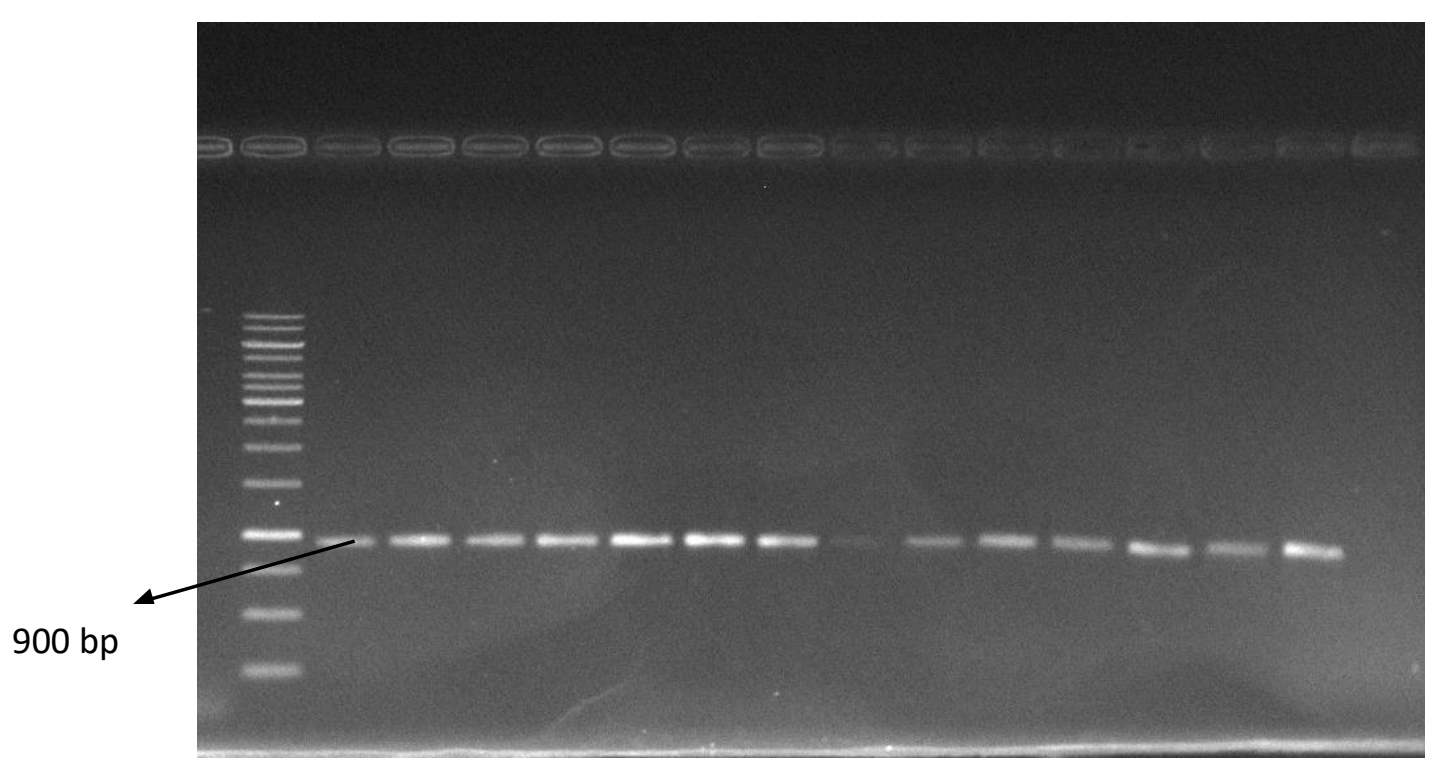

Figure 1. PCR screening of $16 \mathrm{~S}$ rRNA gene from Listeria species

Lanes 1:10000 bp (O’Gene Ruler DNA marker); 2: Positive control (L. monocytogenes ATCC 7644); 3 -

15: L6, L10, L20, L28, L29, L32, L37, L38, L46, L47, L48, L49, L50; 16: Negative control

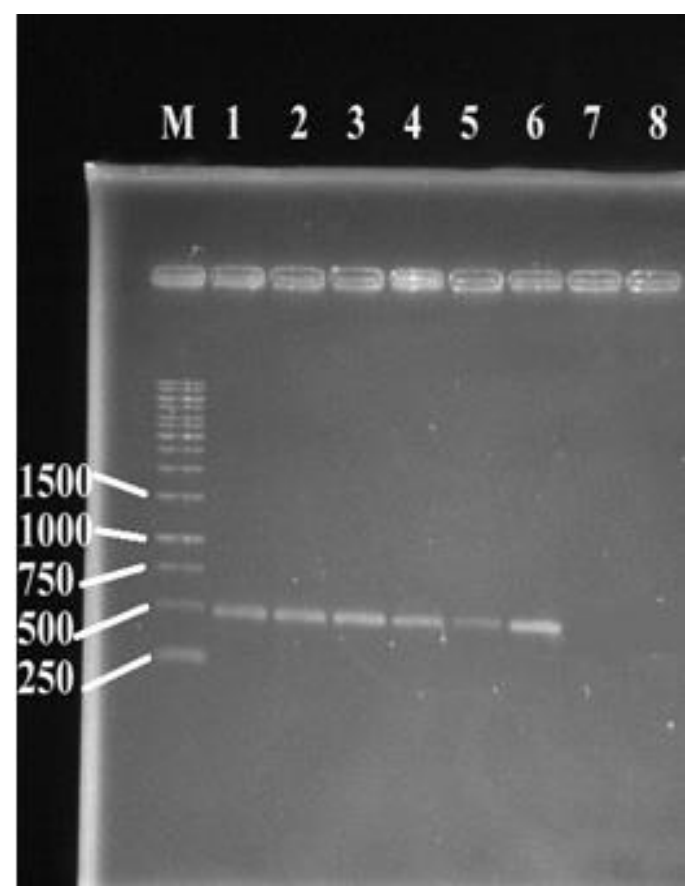

Figure 2. PCR screening of blyA fragments from L. monocytogenes

Lanes M:10000 bp (O’Gene Ruler DNA marker); 1: Positive control (L. monocytogenes ATCC 7644); 2-6: L32, L37, L38, L46, L47; 7-8: Negative control 
Table 1. Incidence of L. monocytogenes and other Listeria spp. in raw milk and dairy products

\begin{tabular}{|l|c|c|c|c|c|c|c|c|c|c|c|}
\hline \multirow{2}{*}{$\begin{array}{l}\text { Nature of } \\
\text { Samples }\end{array}$} & \multirow{2}{*}{$\begin{array}{c}\text { Number } \\
\text { of } \\
\text { Samples }\end{array}$} & \multicolumn{2}{|c|}{$\begin{array}{c}\text { L. } \\
\text { monocytogenes }\end{array}$} & \multicolumn{2}{|c|}{ L. innocua } & \multicolumn{2}{|c|}{ L. ivanovii } & \multicolumn{2}{|c|}{$\begin{array}{c}\text { L. } \\
\text { welshimeri }\end{array}$} & \multicolumn{3}{|c|}{ Total } \\
\hline Raw Milk & 25 & 3 & 12.00 & 3 & 12.00 & 1 & 4.00 & 2 & 8.00 & 9 & 8.19 \\
\hline $\begin{array}{l}\text { Pasteurized } \\
\text { Milk }\end{array}$ & 25 & $-\mathrm{b}$ & - & - & - & - & - & - & - & - & - \\
\hline White Cheese & 30 & - & - & 1 & 3.33 & 1 & 3.33 & 2 & 6.67 & 4 & 3.64 \\
\hline $\begin{array}{l}\text { Homemade } \\
\text { Cheese }\end{array}$ & 30 & 2 & 6.67 & 3 & 10 & 4 & 13.33 & 1 & 3.33 & 10 & 9.09 \\
\hline Total & 110 & 5 & $4.55^{\mathrm{c}}$ & 7 & $6.36 \mathrm{c}$ & 6 & $5.45 \mathrm{c}$ & 5 & $\begin{array}{c}4.55 \\
\mathrm{c}\end{array}$ & 23 & $\begin{array}{c}20.91 \\
\mathrm{c}\end{array}$ \\
\hline
\end{tabular}

a number of positive samples

b not detected

c calculated for total of 110 samples

The contamination rate of Listeria spp. was observed in $36 \%$ of raw milk samples. Among these contaminated samples, $12 \%$ harbored $L$. monocytogenes. The isolates L. innocua (12\%), L. welshimeri ( $8 \%$ ), and L. ivanovi (4\%), were observed in raw milk. The number of the isolates of $L$. monocytogenes obtained in our study was not similar to the other investigators from Turkey. VardarÜnlü et al. (1998), Sağun et al. (2001), Aygun and Pehlivanlar (2006), Taşç et al. (2010), Abay et al. (2012), Kevenk (2014), and Durmaz et al. (2015), reported that raw milk contained $L$. monocytogenes were found to be $4 \%$ in Sivas, $1.2 \%$ in Van, $0 \%$ in Antakya, 2.4\% in Burdur, $0 \%$ in Kayseri, $5 \%$ in Samsun, and $2.1 \%$ in Southeastern Anatolia, respectively. Our findings were higher than these results. Our results were also comparable to other surveys on raw milk conducted in other countries. Kongo et al. (2006) indicated that $1.9 \%$ of raw milk samples analyzed in Portugal were positive for $L$. monocytogenes and also no other Listeria spp. were isolated. Furthermore, isolation rates of $L$. monocytogenes from raw milk was $1.9 \%$ in Portugal (Kongo et al., 2006), 10.96\% in Syria (Al-Mariri et al., 2013), 8.33\% in Morocco (Marnissi et al., 2013), 5.8\% in India (Soni et al., 2013), 2.04\% in Ethiopia (Seyoum et al., 2015), 6.55\% in Nigeria (Usman et al., 2016), and $1.46 \%$ in Cyprus (Botsaris et al., 2016).

Contamination of raw milk may occur in a dairy farm. In addition, the source of $L$. monocytogenes contaminations could be: i) poor quality of silage, ii) inadequate cleanliness of animals, iii) poor hygienic conditions which could occur during milking, storage and transport, iv) infected cows in dairy farms (Marnissi et al., 2013; Telli et al., 2016).

In white cheese, L. welshimeri (6.67\%), L. innocua $(1.33 \%)$, and L. ivanovi $(1.33 \%)$ were detected. The contamination rate of Listeria spp. was observed in $16 \%$ of white cheese samples. L. monocytogenes was not isolated from white cheese. In other reports conducted with white cheese sold in Turkey, isolation rates of $L$. monocytogenes was $6 \%$ in Afyonkarahisar (Akkaya and Alişarlı, 2006), $9.5 \%$ in Kayseri (Kum et al., 2011), 3\% in Erzincan (Azak et al., 2012), 2\% in Balıkesir (Gökmen et al., 2016), 15.77\% in Tekirdağ (Kaptan, 2016), and 3.53\% in Konya (Telli et al., 2016). These results mentioned above were higher than our findings. In contrast to our results, prevalence of Listeria spp. in white cheese sold in Turkey was $33.1 \%$ in Bolu (Arslan and Özdemir, 2008) and $21.5 \%$ in Tekirdağ (Kaptan, 2016). A lower incidence of Listeria spp. was found by Gökmen et al. (2016) in Balıkesir and Telli et al. (2016) in Konya, who determined that $14 \%$ and $8.85 \%$ of white cheese samples were contaminated, respectively. The prevalence of $16 \%$ obtained for Listeria spp. in this study was comparable to other surveys conducted in other countries on white cheese. Kongo et al. (2006) did 
not detect Listeria spp. in cheese samples in Portugal. The report from Seyoum et al. (2015) indicated that $60 \%$ cheese samples were contaminated with Listeria spp. The study performed by Elshinaway et al. (2017), Listeria spp. was detected in $12.5 \%$ in the white cheese. Large numbers of viable Listeria cells present in milk are killed by heat treatment applied through cheese-making (Coroneo et al., 2016). However, cross contamination is a major problem during the cheese production. Contamination sources may be: i) the contaminated raw milk, ii) environment conditions and unclean equipments, and iii) insufficient heat treatment of milk to kill the organisms (Kasalica et al., 2011; Telli et al., 2016). In addition, there are several factors of reproducing of Listeria spp. and specially $L$. monocytogenes in cheese: i) the type and composition of cheese, ii) the resistance of Listeria to the decreased $\mathrm{pH}$ during cheese production, iii) moisture percentage, iv) salt percentage, v) ripeness of cheese, vi) storage conditions, and vii) starter cultures (Elshinaway et al., 2017).

The contamination rate of Listeria spp. was observed in $33.33 \%$ of homemade cheese samples. The most common species isolated in homemade cheese was L. ivanovii $(13.33 \%)$; the remaining Listeria isolates were L. innocua $(10 \%)$, L. monocytogenes $(6.67 \%)$, and L. welshimeri $(3.33 \%)$. In other report conducted with homemade cheeses in Turkey presented by Kaptan (2016) showed that $21.50 \%$ of homemade cheese samples were contaminated with Listeria spp. and $L$. monocytogenes was the most prevalent species with $73.3 \%$ isolates recovered. In countries other than Turkey, the prevalence of Listeria spp. in traditional cheese samples was reported as $16.7 \%$ in Brazil (Silva et al., 2003), $12.2 \%$ in Brazil (Abrahao et al., 2008), 9.8\% in Spain (Arrese and Arroyo-Izaga, 2012), 15\% in Iran (Rahimi et al., 2012), 50\% in Iran (Moosavy et al., 2014), and $10 \%$ in Egypt (Elshinaway et al., 2017). In this study, a higher frequency of $L$. ivanovii in homemade cheese than white cheese was observed. The highest presence of L. ivanovii in home-made cheese samples could be linked with listeriosis risk. Traditional cheeses are currently produced from pasteurized milk in modern dairy industry. Small-sized factories produced dairy products may uncontrol and therefore, they produce non-hygienic cheeses (Kaptan, 2016).

\section{CONCLUSIONS}

The results of current study provide information about the contamination status of raw milk and dairy products sold in Ankara with Listeria spp. This study demonstrated that raw milk and dairy products was not safe for the presence of Listeria spp. We found that L. innocua was the most prevalent species, which is followed by $L$. ivanovii. The highest prevalence of Listeria spp. was found in homemade cheeses, followed by raw milk, and white cheese. According to microbiological criteria of cheese in Turkish Food Codex, $L$. monocytogenes must not found in cheese samples analyzed. However, in this present study, homemade cheeses were found with $L$. monocytogenes. $L$. monocytogenes was also isolated from raw milk. We suggest that hygienic conditions should still be enforced in order to minimize the count of Listeria spp. and L. monocytogenes in dairy industry.

\section{ACKNOWLEDGEMENTS}

The authors thank Ankara University Scientific Research Projects Coordination Unit (Project number 15B0443010) for financial assistance. We also thank Prof. Dr. A. Kadir HALKMAN (Ankara University) for supplying reference strain.

\section{REFERENCES}

Abay, S., Aydın, F., Sümerkand, A.B. (2012). Molecular typing of Listeria spp. isolated from different sources. Ankara Üniv. Vet. Fak. Derg., 59: 183-190.

Abrahao, W.M., Abrahao, P.R.S., Monteiro, C.L.B., Pontarolo, R. (2008). Occurrence of Listeria monocytogenes in cheese and ice cream produced in the State of Prana, Brazil. Braz J. Pharm. Sci., 44: 289-296.

Akkaya, L., Alişarlı, M. (2006). Afyonkarahisar'da tüketime sunulan peynirlerde Listeria monocytogenes ve Salmonella spp. varllı̆ının belirlenmesi. Y.Y.Ü. Vet. Fak.Derg., 17(1-2): 87-91. 
Al-Mariri, A., AbouYounes, A., Ramadan, L. (2013). Prevalence of Listeria spp. in Raw Milk in Syria. Bulg. J. Vet. Med., 16(2): 112-122.

Anonymous. (2011). Resmi Gazete. Türk Gida Kodeksi Mikrobiyolojik Kriterler Yönetmeliği, Say1: 28157 (3. Mükerrer).

Anonymous. (2017). Taxonomy Browser. https://www.ncbi.nlm.nih.gov/Taxonomy/ Browser, Access Date: (24.03.2017).

Anonymous. (2018a). Centers of Disease Control and Prevention. https://www.cdc.gov/listeria/ index.html, Access Date: (09.02.2018).

Anonymous. (2018b). EFSA European Food Safety Authority. https://www.efsa.europa.eu/ en/press/news/161216. Access Date: (09.02.2018).

Anonymous. (2018c). Turkish Food Safety Association. http://www.ggd.org.tr/icerik.php. $\mathrm{id}=340$. Access Date: (09.02.2018).

Arrese, E., Arroyo-Izaga, M. (2012). Prevalence of Listeria monocytogenes in Idiazabal cheese. Nutr. Hosp., 27(6): 2139-2141.

Arslan, S., Özdemir, F. (2008). Prevalence and antimicrobial resistance of Listeria spp. in homemade white cheese. Food Control, 19: 360363.

Aygun, O., Pehlivanlar, S. (2006). Listeria spp. in the raw milk and dairy products in Antakya, Turkey. Food Control, 17: 676-679.

Azak, M. G., Kılıç, H., Hızlısoy, H., Abay, S. (2012). Erzincan ili tulum peynirlerinden Listeria spp. İzolasyonu ve İdentifikasyonu. Erciyes Üniv. Vet. Fak. Derg., 9(3): 149-156.

Barre, L., Angelidis, A.S., Boussaid, D., Brasseur, E.D., Manso, E., Besse, N.G. (2016). Applicability of the EN ISO 11290-1 standard method for Listeria monocytogenes detection in presence of new Listeria species. Int. J. Food Microbiol., 238: 281-287.

Beasley, S. S., Saris, P. E. J. (2004). NisinProducing Lactococcus lactis Strains Isolated from Human Milk. Appl. Environ. Microbiol., 70(8): 50515053.
Blaiotta, G., Pepe, O., Mauiello, G., Villani, F., Andolfi, R., Moschetti, G. (2002). 16S-23S rDNA intergenic spacer region polymorphism of Lactococcus gavriae, Lactococcus raffinolactis and Lactococcus lactis as revealed by PCR and nucleotide sequence analysis system. Appl.Environ. Microbiol., 25: 520-527.

Botsaris, G., Nikolaou, K., Liapi, M., Pipis, C. (2016). Prevalence of Listeria spp. and Listeria monocytogenes in cattle farms in Cyprus using bulk tank miilk samples. J. Food Saf., 36: 482-488.

Coroneo, V., Carraro, V., Aissani, N., Sanna, A., Ruggeri, A., Succa, S., Meloni, B., Pinna, A., Sanna, C. (2016). Detection of Virulence Genes and Growth Potential in Listeria monocytogenes Strains Isolated from Ricotta Salata Cheese. J. Food Sci., 81(1): M114-M120.

Durmaz, H., Avc1, M., Aygün, O. (2015). The Presence of Listeria Species in Corn Silage and Raw Milk Produced in Southeast Region of Turkey. Kafkas Univ. Vet. Fak.Derg., 21:41-44.

Elshinaway, S.H., Meshref, A.M.S., Zeinhom, M.M.A., Hafez, D.A.A. (2017). Incidence of Listeria Species in Some Dairy Products InbeniSuef Governorate. Assiut. Vet. Med. J., 63: 5-13.

Gebretsadik, S., Kassa, T., Alemayehu, H., Huruy, K., Kebede, N. (2011). Isolation and characterization of Listeria monocytogenes and other Listeria species in foods of animal origin in Addis Ababa, Ethiopia. J. Infect. Public Health, 4: 22-29.

Gökmen, M., Akkaya, L., Kara, R., Önen, A. (2016). Prevalence of Salmonella spp. and $L$. monocytogenes in some ready to eat foods sold retail in Balikesir. Van Vet. J., 27(1): 31-36.

Hellberg, R.S., Martin, K.G., Keys, A.L., Haney, C.J., Shen, Y., Smiley, R.D. (2013). 16 S rRNA partial gene sequencing for the differentiation and molecular subtyping of Listeria species. Food Microbiol., 36: 231-240.

Jamali, H., Chai, L.C., Thong, K.L. (2013). Detection and Isolation of Listeria spp. And Listeria monocytogenes in ready-to-eat foods with various selective culture media. Food Control, 32: 19-24. 
Kaptan, B. (2016). Prevalence of Listeria spp. and L. monocytogenes in Homemade Pottery Cheese. Tekirdağ Ziraat Fak. Derg., 13: 80-87.

Kasalica, A., Vukovic, V., Vranjes, A., Memisi, N. (2011). Listeria monocytogenes in milk and dairy products. Biotechn. Anim. Husbandary, 27(3): 10671082.

Kevenk, T. O. (2014). Süt ve Ürünlerinde Listeria monocytogenes'in İnsidensi, Serotiplendirilmesi ve Antibiyotik Dirençliliklerinin Belirlenmesi. Ondokuz Mayıs Üniversitesi Sağlık Bilimleri Enstitüsü Besin Hijyeni ve Teknolojisi Anabilim Dalı Doktora Tezi, Samsun, Türkiye, 116 sayfa.

Kongo, J. M., Malcata, F.X., Ho, A. J., Wiedmann, M. (2006). Detection and Characterization of Listeria monocytogenes in Sao Jorge (Portugal) Cheese Production. J. Dairy Sci., 89: 4456-4461.

Korsak, D., Szuplewska, M. (2016). Characterization on nonpathogenic Listeria species isolated from food and food processing environment. Int. J. Food Microbiol., 238: 274-280.

Kum, E., Yıldırım, Y., Ertaş, N. (2011). Kayseri'de Satışa Sunulan Peynir Örneklerinde Listeria monocytogenes Varlığının Klasik Kültür Yöntemi ile Belirlenmesi. Erciyes Üniv. Vet. Fak. Derg., 8(2): 105-109.

Marnissi, B. E., Bennani, L., Cohen, N., Lalami, A.E. O., Belkhou, R. (2013). Presence of Listeria monocytogenes in raw milk and traditional dairy products marketed in the North-central region of Morocco. Afr. J. Food Sci., 7(5): 87-91.

Milillo, S. R., Friendly, E. C., Saldivar, J. C., Muthaiyan, A., O’Brian, C., Crandall, P. G., Johnson, M. G., Ricke, S. C. (2012). A review of the ecology, genomics, and stres response of Listeria innocua and Listeria monocytognes. Crit. Rev.Food Sci. Nutr., 52: 712-725.

Momtaz, H., Yadollahi, S. (2013). Molecular Characterization of Listeria monocytogenes isolated from fresh sea food samples in Iran. Diagn. Pathol., 8: 149 .

Moosavy, M. M., Esmaeili,S., Mostafavi, E., Amiri, F.B. (2014). Isolation of Listeria monocytogenes from milks used for Iranian traditional cheese in Lighvan cheese factories. Ann. Agric. Environ. Med., 21(4): 728-729.

Natratilova,P., Schlegelova, J., Sustackova, A., Napravnikova, E., Lukasova, J. (2004). Prevalence of Listeria monocytogenes in milk, meat and foodstuff of animal origin and the phenotype of antibiotic resistance of isolated strains. Vet. Med. Czech, 49: 243-252.

Odetokun, I.A., Adetunji, V.O. (2016). Prevalence and persistence of Listeria monocytogenes in dairy and other ready-to-eat food products in Africa. Microbes in Food and Health, 319: 349-361.

Paziak-Domanska, B., Bogulawska, E., Wiekowska-Szakiel, M., Kotlowski, R., Rozalska, B., Chmiela, M., Kur, J., Dabrowski, W., Rudnicka, W. (1999). Evaluation of the API test, phosphatidylinositol-specific phospholipase C activity and PCR method in identification of Listeria monocytogenes in meat foods. FEMS Microbiol. Lett.,171: 209-214.

Phraephaisarn, C., Khumthong, R., Takahashi, H., Ohshima, C., Kodama, K., Techaruvichit, P., Vvesaratchavest, M., Taharnklaew, R., Keeratipibul, S. (2017). A novel biomarker for detection of Listeria species in food processing factory. Food Control, 73: 1032-1038.

Rahimi, E., Momtaz, H., Sharifzadeh, A., Behzadnia, A., Ashtari, M.S., Esfahani, S.Z., Riahi, M., Momeni, M. (2012). Prevalence and Antimicrobial Resistance of Listeria Species Isolated from Traditional Dairy Products in Chahar Mahal \& Bakhtiyari, Iran. Bulgarian J. Vet. Med., 15: 115-122.

Reda, W.W., Abdel-Moein, K., Hegazi, A., Mohamed, Y., Abdel-Razik, K. (2016). Listeria monocytogenes:An emerging food-borne pathogen and its public health implications. J. Infect. Dev. Ctries, 10(2): 149-154.

Sağun, E., Sancak, Y.C., İşleyici, Ö., Ekici, K. (2001). Van ve Çevresi Süt ve Otlu Peynirlerinde Listeria Türlerinin Varllğı ve Yayginlığ1 Üzerine Bir Araştırma. Turk. J. Vet. Anim. Sci., 25: 15-19.

Saludes, M., Troncoso, M., Figuero, G. (2015). Presence of Listeria monocytogenes in Chilean food matrices. Food Control, 50: 331-335. 
Sarfaz, M., Ashraf, Y., Ashraf, S. (2017). A Review:Prevalence and antimicrobial susceptibility profile of Listeria species in milk. Matrix Sci. Med., 1(1): 03-09.

Sarker, R., Ahmed, S. (2015). Prevalence and Antimicrobial Susceptibility of Listeria spp in Dairy Food Products and Water Samples in Dhaka, Bangladesh. J. Life Sci., 9: 152-158.

Seyoum, E.T., Woldetsadik, D.A., Mekonen, T.K., Gezahegn, H.A., Gebreyes, W.A. (2015). Prevalence of Listeria monocytogenes in raw bovine milk and milk products from central highlands of Ethiopia. J. Infect. Dev. Ctries., 9: 1204-1209.

Silva, I.M.M., Almeida, R.C.C., Alves, M.A.O., Almedia, P.F. (2003). Occurrence of Listeria spp. in critical control points and the environment of Minas Frescal cheese processing. Int. J. Food Microbiol., 81: 241-248.

Soni, D., Singh, R., Singh, D., Dubey, S. (2013). Characterization of Listeria monocytogenes isolated from Ganges water, human clinical and milk samples at Varanasi, India. Infect. Genet. Evol., 14: 83-91.

Taşç1, F., Türütoğlu, H., Öğütçü, H. (2010). Investigations of Listeria Species in Milk and Silage Produced in Burdur Province. Kafkas Univ. Vet. Fak. Derg., 16: 93-97.
Telli, N., Güner, A., Dönmez, F.S., Özdemir, Ö.Ö. (2016). Detection of the contamination sources of Listeria monocytogenes in pickled white cheese production process line and genotyping with the pulsed-field gel electrophoresis method. Turk. J. Vet. Anim. Sci., 40: 630-636.

TS EN ISO 11290-1:1996 Microbiology of food and animal feding stuffs-Horizontal method for the detection and enumeration of Listeria monocytogenes-Part 1: Detection method.

Usman, U. B., Kwaga, J. K. P., Kabir, J., Olonitola, O.S. (2016). Isolation and antimicrobial suspectibility of Listeria monocytogenes from raw milk and milk products in Northern Kaduna State, Nigeria. J. Appl. Environ. Microbiol., 4(3): 46-54.

Vardar-Ünlü, G., Ünlü, M., Bakıc1, M.Z. (1998). Incidence of Listeria spp from raw milk in Sivas. Tr. J. Medical Sci., 28: 389-392.

Yehia, H.M., Ibraheim, S.M., Hassanein, W.A. (2016). Prevalence of Listeria species in some foods and their rapid identification. Trop. J. Pharm. Res., 15: 1047-1052. 